\title{
駅前広場 の現状と問題点
}

近代都书の欠宿と矛盾は，都市交通に集中的にあらわ れてきた。そして駅前広場《都市交通の接点としての面 が強くなってきた。都抒の発展は，鉄道旅客駅を誘引寸 るが逆に鉄道の旅客駅㷙を中心にして都市位発展してい く。都市の性格が高度化し, 複雑になるにつれて, 駅前 広場についても，いるいるな開題が起ってきた。ここに 国鉄に新ける駅前広場の現状をとらえ，著下の考察を試 みてみをい。

\section{1.国鉄における駅前広場の面積}

国鉄に掠计る駅前広場の現沉を考察する第 1 步として

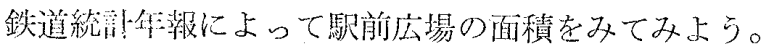

外見上统なんらの区分をない平面的な駅前底瑒であっ ても，用地の所有権が「国鉄側」と「都氿側」に区分さ れているところが多い。駅前広場についての諸問題が発 生与るひとつの源泉となっている。「国鉄側」に所属す る虽㓩広場面積の割合は約 $90 \%$ であり，「都市側」のそ れ約 $10 \%$ である。最近では「都括側」の比重がやぬ 增加していく傾向にある。

国鉄駅前広場面積の年度别守方勢㤝，昭和 30 年度を 100 として，34 年 104，38 年 107 とわずか以增加してい る。これを国鉄旅客取扱駅と刘比してみると，客货双方 在报方一般駅性，30 年 $3710 ， 34$ 年 $3647 ， 38$ 年 2811 と验少しているが，「旅客専用」の駅情增加し，两者を 合せた旅客取挾駅は 30 年度 4420 氺ら 38 年 4954 と 增加している。戈方勢比率は 30 年を 100 として，34 106, 38 年 112 で, 駅前広場面積の増加率を上回ってい る。これ注新設の旅客駅は概して，墩地に多く，広場の 面積も少小ためである。一駅平均の広場面積は 38 年に ついてみると 859 平方メートルである。

国鉄の線別にみた駅前広場面積のらち，「都市側」面 積の比率の高い線を選んで夕ると，徳島本 線の $43 \%$, 宇品線の $40 \%$ ，山乎線の $38 \%$ ，横須賀線の $36 \%$ がめ だっている。

\section{2. 駅前広場拡張に伴う造成蒷用分担の問題}

最近は都淤部画の要請による駅前広場の造成は增加の 傾向にある。

駅前広場造成の多くは，国鉄の営業政策上の必要とい うよりは，都市計画の要請によるものである。その造成

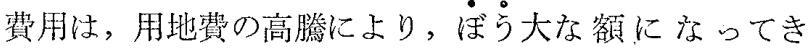
た。ここに一つの閭題が生じてきた。

跀前広場造成費用分担については，昭和 21 年 7 月 13

\section{正会員鹿鼠喜 久子水}

日に当時の運輸省と内務省抢よび，戦災復興院との三者 による申合せ事項があり，運輸省と地元奇町村などで折 半することになり，今日におよんでいる。

この申合せ事項は，大平洋戦争の戦㷋地および建物踈 開地に晾ける復興を目的としたものであって，当時とは 事情の買った今日で注，新たな観点から検詩する必要が ある。

\section{3. 駅前広場管理の問題}

都市の発展による駅前広埸の性格の変化と, 用地所有 権が複雑になるにつれて，新たに駅前広場の管理につい ても問題が生じてきた。現在, 駅前庆場の造成は, 都市 計画事業として施行されているが，都市計画法では，完 成後の管理注実際上不闭能に近い。と寸れば管理の主体 となるべきものはその土地の所有者となってくる。しか し実際には国鉄と地元师町村が，歩調をそるえて管理す ることはいろいろな困難がある。

元来駅前広場は一体として設計されており，したがっ て一体として運営され秝ばならない。又個々の土地所有 者独自の立場を離れて，これを使用する旅客と市民の立 場から考えるべきであろう。さらに都市の発展に伴って 既成师街地内の既成駅の乘降人員の一層の增加が考えら れ, 駅前広場の䙺模拉張, 立体化等, 広場の性格, 形態 管理について一層の検討が必要である。

$$
\text { 表-1 }
$$

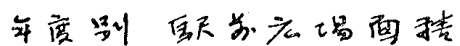

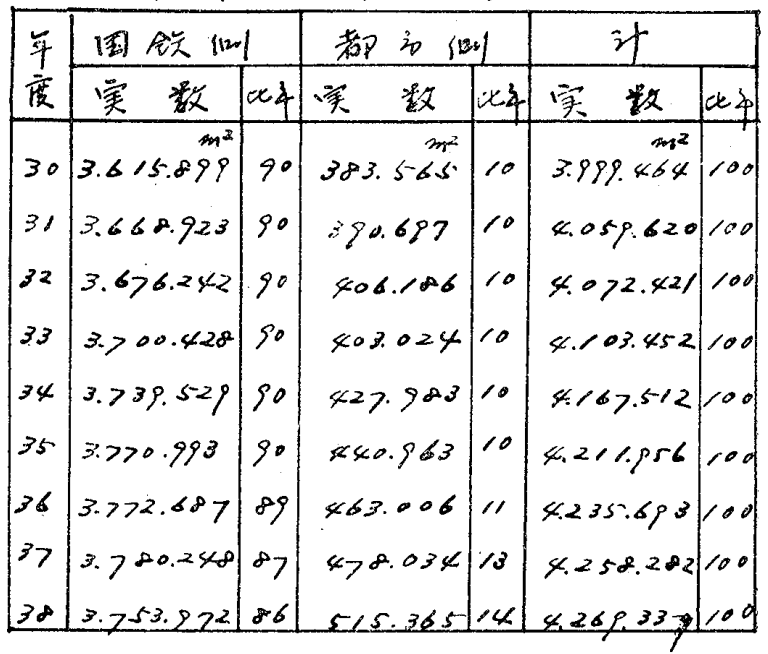

$*$ 工学院大学大学院生 